\title{
Mobile attachment for automated crack milling
}

\author{
Birte Froebus $^{1}$, Sascha Gentes ${ }^{1}$, and Christoph Unverzagt ${ }^{2}$ \\ ${ }^{1}$ Karlsruhe Institute of Technology (KIT) - Institute for Technology and Management in Construction (TMB), \\ 76131 Karlsruhe, Germany \\ ${ }^{2}$ Herrenknecht AG, 77936 Schwanau, Germany \\ Correspondence: Birte Froebus (birte.froebus@kit.edu)
}

Published: 10 November 2021

\begin{abstract}
In the dismantling of nuclear facilities, the decontamination and remote-controlled crushing of reinforced concrete is a central point. The main objective is to selectively remove the contaminated material in order to feed the remaining material, which in relation to the overall system or overall mass, represents the predominant part of the normal recycling cycle. For the surface decontamination of the upper millimeters, several methods are available that are constantly being optimized and further developed. However, there is a great need for research in the demolition and selective deep removal of reinforced concrete, e.g. in the case of cracks or eruptions into which contamination could penetrate, or the removal of metallic fixtures. The production of freely measurable surface geometries is a constant objective (Edelmann et al., 2018).

The German "Defined removal of highly reinforced concrete" (DefAhS) research project was funded by the German Federal Ministry of Education and Research (BMBF) from October 2013 to the end of March 2018. In the course of the project, a new combination tool consisting of indexable inserts and impact lamellas was developed. With this method it is possible to remove highly reinforced concrete in one operation. The following property right could be granted: "Device for removing building material" (DE102015114122B3). Within the research project, concrete, reinforcement and fixtures (dowels, rails, anchor plates, pipe penetrations) could be successfully cut. It could also be shown that it is possible to remove several layers of steel reinforcement within a concrete matrix.

The "Mobile attachment for automated crack milling" (MAARISS) research project has been running since November 2020. The hybrid milling technology developed in DefAhS is intended to form the basis for the milling drum used in MAARISS. The aim in MAARISS is, among other things, a new development of the extraction system directly on the removal unit and an automation system for use in a nuclear facility. Cracks are to be automatically milled over in order to enable subsequent clearance measurement by the staff on site. The physically very strenuous work of crack uncovering should be reduced to just one operator in a safe environment. The construction of a scaffold should be completely dispensed with and existing transport technology (forklift or lifting platform) should be used.
\end{abstract}

Kurzfassung. Beim Rückbau kerntechnischer Anlagen sind die Dekontaminierung und ferngesteuerte Zerkleinerung von Stahlbeton eine zentrale Aufgabe. Hauptziel ist, das verunreinigte Material gezielt zu entfernen, um das verbleibende Material, das bezogen auf das Gesamtsystem bzw. die Gesamtmasse den überwiegenden Teil darstellt, dem normalen Recyclingkreislauf zuzuführen. Für die Oberflächendekontaminierung der oberen Millimeter stehen mehrere Verfahren zur Verfügung, die ständig optimiert und weiterentwickelt werden. Es besteht jedoch großer Forschungsbedarf bezüglich des Abbruchs und selektiven Tiefenabtrags von Stahlbeton, z. B. bei Rissen oder Abplatzungen und Ausbrüchen, in die Verunreinigungen eindringen könnten, oder dem Entfernen von metallischen Einbauten. Ziel dabei ist immer, für Freimessungen zugängliche Oberflächengeometrien zu erhalten (Edelmann et al., 2018).

Das Forschungsprojekt DefAhS (definierter Abtrag hochbewehrter Stahlbetonstrukturen) wurde vom Bundesministerium für Bildung und Forschung (BMBF) von Oktober 2013 bis Ende März 2018 gefördert. Im Zuge dieses Projekts wurde ein neues Kombinationswerkzeug, bestehend aus Wendeschneidplatten und 
Schlaglamellen, entwickelt. Mit diesem Verfahren ist es möglich, hochbewehrten Beton in einem Arbeitsgang zu entfernen. Folgende Schutzrechte wurden genehmigt: „Vorrichtung zum Abtragen von Bauwerkstoff“ (DE102015114122B3). Im Forschungsprojekt konnten Beton, Bewehrung und Einbauten (Dübel, Schienen, Ankerplatten, Rohrdurchführungen) erfolgreich geschnitten werden. Es konnte auch nachgewiesen werden, dass es möglich ist, mehrere Lagen Stahlbewehrung innerhalb einer Betonmatrix zu entfernen.

Seit November 2020 läuft das MAARISS-Forschungsprojekt „,mobiles Anbaugerät zum automatisierten Rissfräsen“. Die in DefAhS entwickelte Hybridfrästechnologie soll die Basis für die bei MAARISS eingesetzte Frästrommel bilden. Ziel bei MAARISS ist u. a. eine Neuentwicklung des Absaugsystems direkt auf der Entnahmeeinheit und eines Automatisierungssystema für den Einsatz in einer kerntechnischen Anlage. Risse sollen automatisch überfräst werden, um eine nachfolgende Freimessung durch das Personal vor Ort zu ermöglichen. Die körperlich sehr anstrengende Arbeit der Rissfreilegung soll in einer sicheren Umgebung auf nur einen Bediener reduziert werden. Auf den Bau eines Gerüsts sollte komplett verzichtet und vorhandene Transporttechnik (Stapler oder Hebebühne) genutzt werden.

Financial support. This research has been supported by the Bundesministerium für Bildung und Forschung (grant no. 15S9425).

\section{References}

Edelmann, T., Cousseau, F., Gentes, S., Kaiser, S., Friedrich, S., Geimer, M., Engelmann, D., Steringer, A., Braun, J., Kisling, M., Schmidt, A., Denkena, B., and Hess, U.: Abschlussbericht über das Forschungsvorhaben „Definierter Abtrag hochbewehrter Stahlbetonstrukturen (DefAhS)“, Karlsruhe, Schwanau, Hannover, Heidelberg, Germany, 2018. 